ARTICLE

\title{
Tuning local chemistry of P2 layered-oxide cathode for high energy and long cycles of sodium-ion battery
}

Chenchen Wang ${ }^{1}$, Luojia Liu' ${ }^{1}$ Shuo Zhao ${ }^{1}$, Yanchen Liu' ${ }^{1}$, Yubo Yang ${ }^{2}$, Haijun Yu (D) ${ }^{2}$, Suwon Lee ${ }^{3}$, Gi-Hyeok Lee ${ }^{4,5}$, Yong-Mook Kang ${ }^{3}$, Rong Liu ${ }^{6}$, Fujun Li (1) ${ }^{1 凶} \&$ Jun Chen (i) ${ }^{1}$

Layered transition-metal oxides have attracted intensive interest for cathode materials of sodium-ion batteries. However, they are hindered by the limited capacity and inferior phase transition due to the gliding of transition-metal layers upon $\mathrm{Na}^{+}$extraction and insertion in the cathode materials. Here, we report that the large-sized $\mathrm{K}^{+}$is riveted in the prismatic $\mathrm{Na}^{+}$ sites of $\mathrm{P} 2-\mathrm{Na}_{0.612} \mathrm{~K}_{0.056} \mathrm{MnO}_{2}$ to enable more thermodynamically favorable $\mathrm{Na}^{+}$vacancies. The $\mathrm{Mn}-\mathrm{O}$ bonds are reinforced to reduce phase transition during charge and discharge. $0.901 \mathrm{Na}^{+}$per formula are reversibly extracted and inserted, in which only the two-phase transition of $\mathrm{P} 2 \leftrightarrow \mathrm{P}^{\prime} 2$ occurs at low voltages. It exhibits the highest specific capacity of 240.5 $\mathrm{mAh} \mathrm{g}^{-1}$ and energy density of $654 \mathrm{Wh} \mathrm{kg}^{-1}$ based on the redox of $\mathrm{Mn}^{3+} / \mathrm{Mn}^{4+}$, and a capacity retention of $98.2 \%$ after 100 cycles. This investigation will shed lights on the tuneable chemical environments of transition-metal oxides for advanced cathode materials and promote the development of sodium-ion batteries.

\footnotetext{
${ }^{1}$ Key Laboratory of Advanced Energy Materials Chemistry (Ministry of Education), Renewable Energy Conversion and Storage Center (RECAST), College of Chemistry, Nankai University, Tianjin, China. ${ }^{2}$ College of Materials Science and Engineering, Beijing University of Technology, Beijing, China. ${ }^{3}$ Department of Materials Science and Engineering, Korea University, Seoul, Republic of Korea. ${ }^{4}$ Department of Materials Science and Engineering, Dongguk University, Seoul, Republic of Korea. ${ }^{5}$ Advanced Light Source, Lawrence Berkeley National Laboratory, Berkeley, CA, USA. ${ }^{6}$ Secondary lon Mass Spectrometry Facility,

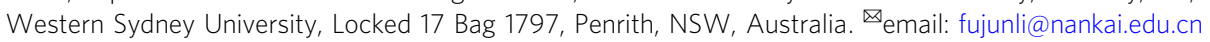


S odium-ion batteries (SIBs) have been considered as one promising next-generation battery system for large-scale energy storage and smart electric grid, due to the low cost and wide distribution of $\mathrm{Na}$ resources ${ }^{1-3}$. The battery performance and cost are mainly governed by the applied cathode materials ${ }^{4-7}$. A wide range of host materials, such as transitionmetal oxides, phosphates, Prussian blue analogs, and so on, have been investigated for reversible (de)intercalation of $\mathrm{Na}^{+}$. However, the intrinsic large ionic radius of $102 \mathrm{pm}$ and molar weight of $\mathrm{Na}^{+}$over its $\mathrm{Li}^{+}$counterpart impose penalties on the specific capacity or the structure stability of cathode materials, which limit the deployment of $\operatorname{SIBs}^{8-12}$. It is rational to design and synthesize cathode materials with more available sites for $\mathrm{Na}^{+}$ storage and robust crystal structure for $\mathrm{Na}^{+}$(de)intercalation, ensuring their large specific capacities and long cycle life.

Layered transition-metal oxides with earth-abundant elements have been actively studied as host materials for $\mathrm{Na}^{+}$storage ${ }^{13,14}$. Sodium manganese oxide with a $\mathrm{P} 2$ phase $\left(\mathrm{P} 2-\mathrm{Na}_{x} \mathrm{MnO}_{2}\right)$ is of significant importance for SIBs, which is consisted of two $\mathrm{MnO}_{6}$ octahedra slabs and sandwiched $\mathrm{Na}$ layers in each unit cell with the ABBA oxygen packing frameworks ${ }^{15,16}$. It usually delivers a capacity of $\sim 160 \mathrm{mAh} \mathrm{g}^{-1}$, corresponding to insertion of $0.60 \mathrm{Na}^{+}$ per formula for $\mathrm{P} 2-\mathrm{Na}_{x} \mathrm{MnO}_{2}{ }^{17,18}$. The limited movable $\mathrm{Na}^{+}$and phase transitions occurring upon its extraction and reinsertion are the major challenges. The $\mathrm{Na}^{+}$extraction to $x<0.35$ in $\mathrm{P} 2-$ $\mathrm{Na}_{x} \mathrm{MnO}_{2}$ results in the irreversible $\mathrm{P} 2 \rightarrow \mathrm{OP} 4$ phase transition, due to gliding of the $\mathrm{MnO}_{2}$-slabs, and consequently decaying capacities in cycles ${ }^{19,20}$. Fe-doping in the $\mathrm{MnO}_{2}$-slabs of $\mathrm{Na}_{x-}$ $\mathrm{Fe}_{0.5} \mathrm{Mn}_{0.5} \mathrm{O}_{2}$ is beneficial for a high capacity of $200 \mathrm{mAh} \mathrm{g}^{-1}$ but with $35 \%$ capacity loss after 30 cycles, which is originated from the $\mathrm{P} 2 \rightarrow \mathrm{O} 2 / \mathrm{OP} 4$ phase transition ${ }^{21}$. The capacity can also be promoted to $185 \mathrm{mAh} \mathrm{g}^{-1}$ by co-doping $\mathrm{Co}$ and $\mathrm{Ni}$ for P2$\mathrm{Na}_{0.7} \mathrm{Mn}_{0.6} \mathrm{Ni}_{0.3} \mathrm{Co}_{0.1} \mathrm{O}_{2}$ (Yoshida et al. ${ }^{22}$ ). Partial Mg substitution for $\mathrm{Mn}$ in $\mathrm{P} 2-\mathrm{Na}_{x} \mathrm{MnO}_{2}$ delays the formation of OP4 phase, leading to smooth electrochemical profiles and extended cycling performance with a capacity of $106 \mathrm{mAh} \mathrm{g}^{-1}$ (Clément et al. ${ }^{19}$ ). The substitution of $\mathrm{Li}$ or $\mathrm{Al}$ in $\mathrm{Na}_{x} \mathrm{MnO}_{2}$ can suppress the JahnTeller distortion and enhance its phase stability ${ }^{23,24}$. It is clear that finely tuning the chemical environments of the $\mathrm{MnO}_{6}$-octahedra with suitable dopants in the place of Mn allows for either more accessible $\mathrm{Na}^{+}$sites for large capacities with limited cycles or minimized slab gliding for long cycles with moderate capacities. However, solutions to such paradox are challenging and highly desirable for the development of SIBs ${ }^{25}$.

Here, we show that the large-sized $\mathrm{K}^{+}$of $138 \mathrm{pm}$ is riveted in the edge-sharing sites of $\mathrm{Na}^{+}$in $\mathrm{P} 2-\mathrm{Na}_{0.612} \mathrm{~K}_{0.056} \mathrm{MnO}_{2}$, which leads to the small interslab distance of $0.56 \mathrm{~nm}$ in $\mathrm{Na}_{0.612} \mathrm{~K}_{0.056} \mathrm{MnO}_{2}$ and results in high diffusion barrier of $\mathrm{K}^{+}$and hence its immobility. The $\mathrm{Na}-\mathrm{O}$ bond strength and $\mathrm{Na}^{+}$vacancy formation energy are reduced to favor more extractable and insertional $\mathrm{Na}^{+}$. The reinforced $\mathrm{MnO}_{6}$-octahedra slabs are beneficial to the structure stability of P2$\mathrm{Na}_{0.612} \mathrm{~K}_{0.056} \mathrm{MnO}_{2}$. In situ X-ray diffraction (XRD) indicates that there is no inferior phase transition at the high charge voltages during cycles. It turns out to exhibit a high specific capacity of $240.5 \mathrm{mAh} \mathrm{g}$ ${ }^{-1}$ with $\mathrm{Mn}^{3+} / \mathrm{Mn}^{4+}$ as the redox couple and the highest energy density of $654 \mathrm{Wh} \mathrm{kg}^{-1}$ with good cycle stability and rate capability.

\section{Results and discussion}

Characterization and structure analysis. $\mathrm{Na}_{0.67-x} \mathrm{~K}_{x} \mathrm{MnO}_{2}(0 \leq$ $x \leq 0.2$ ) was synthesized via a solid-state reaction at $900{ }^{\circ} \mathrm{C}$ in air, however, the pure P2 phase was only obtained with $x \leq 0.1$, as confirmed by the XRD patterns in Fig. 1a and Supplementary Figs. 1 and 2. The optimized composition was found with nominal $x=0.1$. Its exact composition was determined to $\mathrm{P} 2-\mathrm{Na}_{0.612} \mathrm{~K}_{0.056} \mathrm{MnO}_{2}$ by inductively coupled plasma-optical emission spectrometry (ICP-OES) in Supplementary Table 1 . The oxygen non-stoichiometry in the assynthesized $\mathrm{P} 2-\mathrm{Na}_{0.612} \mathrm{~K}_{0.056} \mathrm{MnO}_{2-\delta}$ was determined by iodine stoichiometry titration. As listed in Supplementary Table 2, it shows the atomic ratio of oxygen is 1.985 , which is mainly attributed to oxygen vacancies on its surface ${ }^{26}$. The XRD pattern and Rietveld refinement of $\mathrm{Na}_{0.612} \mathrm{~K}_{0.056} \mathrm{MnO}_{2}$ and $\mathrm{Na}_{0.706} \mathrm{MnO}_{2}$ are displayed in Fig. $1 \mathrm{a}$ and Supplementary Fig. 3, and all the diffraction peaks are assigned to a hexagonal lattice with a space group of $P 6_{3} / \mathrm{mmc}$. The refined structure of $\mathrm{Na}_{0.612} \mathrm{~K}_{0.056} \mathrm{MnO}_{2}$ is depicted along the $y$ and $z$ axes in Fig. 1b, c, respectively. There exist two types of trigonal prismatic sites for $\mathrm{Na}^{+}$, which are sharing faces $\left(\mathrm{Na}_{\mathrm{f}}\right)$ and edges $\left(\mathrm{Na}_{\mathrm{e}}\right)$ with the $\mathrm{MnO}_{6}$-octahedra in the two adjacent slabs, respectively, as depicted in Fig. 1c and Supplementary Fig. 4. The two adjacent Na sites are not accessible at the same time, because of their large electrostatic repulsion. Rietveld refinement indicates that $\mathrm{K}^{+}$is located at the $\mathrm{Na}_{\mathrm{e}}$ site (Supplementary Tables 3 and 4), which is mainly ascribed to the much higher stability of the $\mathrm{Na}_{\mathrm{e}}$ sites $^{27,28}$. Moreover, the interlayer space $\left(d_{(\mathrm{Na}-\mathrm{O}-\mathrm{Na})}\right)$ is enlarged to $3.58 \AA$ in $\mathrm{Na}_{0.612} \mathrm{~K}_{0.056} \mathrm{MnO}_{2}(3.42 \AA$ in $\mathrm{Na}_{0.706} \mathrm{MnO}_{2}$ ) due to the larger ionic radii for $\mathrm{K}^{+}$versus $\mathrm{Na}^{+}$. On the contrary, the $d_{\mathrm{MnO} 2}$ is reduced to $2.02 \AA$ in $\mathrm{Na}_{0.612} \mathrm{~K}_{0.056} \mathrm{MnO}_{2}$ $\left(2.28 \AA\right.$ in $\mathrm{Na}_{0.706} \mathrm{MnO}_{2}$ ), which is resulted from the enhanced $\mathrm{MnO}_{2}$-slabs. Thus, the distances of adjacent $\mathrm{MnO}_{2}$-slabs ( $d$-spacing) are reduced in $\mathrm{K}$-doped compounds even with larger-sized $\mathrm{K}^{+}$in the Na layers.

Synchrotron X-ray pair distribution function (PDF) analysis was performed to study the local structure of $\mathrm{Na}_{0.612} \mathrm{~K}_{0.056} \mathrm{MnO}_{2}$ in Fig. 1d. The P2-type layered structure is consistent with XRD refinement, as depicted in Supplementary Table 5. The Mn-O and Mn-Mn bond lengths are 1.890 and $2.891 \AA$, respectively, which are shorter than those in $\mathrm{Na}_{0.706} \mathrm{MnO}_{2}$ (1.897 and 2.901) in Supplementary Fig. 5 and Table 6 . This suggests the strengthened chemical bonds and reinforced interaction of $\mathrm{MnO}_{6}$-octahedra slabs. X-ray adsorption near-edge structure (XANES) spectra in Supplementary Fig. $6 \mathrm{a}$ imply that $\mathrm{Mn}$ has the approximately same average oxidation states in $\mathrm{Na}_{0.612} \mathrm{~K}_{0.056} \mathrm{MnO}_{2}$ and $\mathrm{Na}_{0.706} \mathrm{MnO}_{2}$. The fitted $\mathrm{Mn} \mathrm{K}$-edge Fourier-transformed extended $\mathrm{X}$-ray adsorption fine structure (FT-EXAFS) spectrum of $\mathrm{Na}_{0.612} \mathrm{~K}_{0.056} \mathrm{MnO}_{2}$ is shown in Fig. 1e, as well as $\mathrm{Na}_{0.706} \mathrm{MnO}_{2}$ in Supplementary Fig. 6b. As listed in Supplementary Tables 7 and 8, it shows shortened bond lengths of Mn-O (1.889 $\AA, 1.895 \AA$ for $\left.\mathrm{Na}_{0.706} \mathrm{MnO}_{2}\right)$ and $\mathrm{Mn}-\mathrm{Mn}(2.889 \AA$, $2.897 \AA$ for $\mathrm{Na}_{0.706} \mathrm{MnO}_{2}$ ). This is in good agreement with the PDF results and the $d$-spacings of 0.56 and $0.57 \mathrm{~nm}$ between the (002) facets in $\mathrm{Na}_{0.612} \mathrm{~K}_{0.056} \mathrm{MnO}_{2}$ and $\mathrm{Na}_{0.706} \mathrm{MnO}_{2}$, respectively, as observed by high-resolution transmission electron microscopy (HRTEM) in Supplementary Fig. 7.

Scanning transmission electron microscopy (STEM) equipped with the detectors of high-angle annular dark field (HAADF) and annular bright field (ABF) are employed to study the atomic structure of $\mathrm{Na}_{0.612} \mathrm{~K}_{0.056} \mathrm{MnO}_{2}$ in Fig. 2a, b and Supplementary Fig. 8, which is $1-10 \mu \mathrm{m}$ in size in Supplementary Fig. 9a. The bright dots in the STEM-HAADF images and the dark dots in STEM-ABF image are assigned to the atomic columns of $\mathrm{Mn}$, between which are the atomic columns of $\mathrm{Na}$ or $\mathrm{K}$. The STEM-HAADF and SEM images in Supplementary Figs. $9 \mathrm{~b}$ and 10 indicate that $\mathrm{Na}_{0.706} \mathrm{MnO}_{2}$ has similar morphology and layered structure with $\mathrm{Na}_{0.612} \mathrm{~K}_{0.056} \mathrm{MnO}_{2}$. Electron energy loss spectroscopy (EELS) in Fig. $2 \mathrm{c}$ and Supplementary Fig. 11 were collected in the selected areas as indicated, in which the peaks of $\mathrm{K} \mathrm{L}$-edge at $297 \mathrm{eV}$ indicate the presence of $\mathrm{K}$ in the $\mathrm{Na}$ layers in $\mathrm{Na}_{0.612} \mathrm{~K}_{0.056} \mathrm{MnO}_{2}$.

Dynamic secondary ion mass spectroscopy (SIMS) is performed to analyze the distribution of elements from the surface to the bulk of $\mathrm{Na}_{0.612} \mathrm{~K}_{0.056} \mathrm{MnO}_{2}$ in Fig. 2d, as well as their elemental mappings in Supplementary Figs. 12 and 13. It is shown that the contents of $\mathrm{K}$ and $\mathrm{Na}$ are increased along with a slight decrease of $\mathrm{Mn}$ in the initial $50 \mathrm{~s}$ of sputtering, and then they are gradually dropped and become constant. The $\mathrm{K}$ profile shows a slight aggregation trend on the 

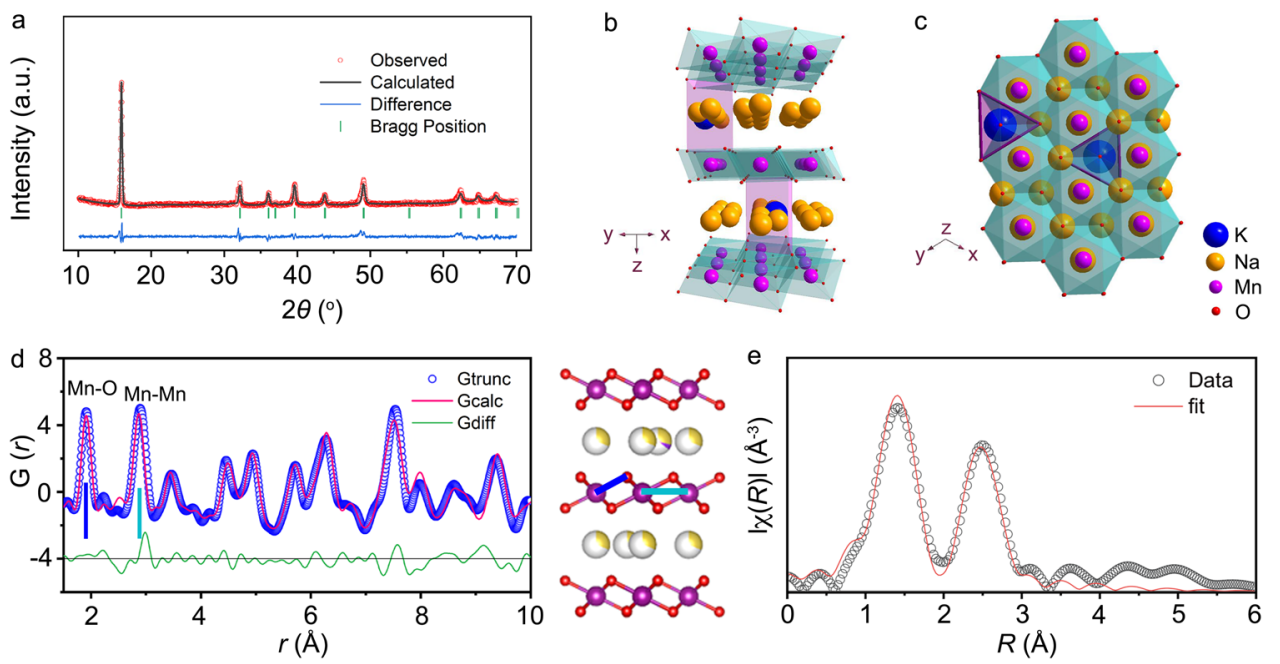

Fig. 1 Crystal structure of $\mathbf{N a}_{\mathbf{0 . 6 1 2}} \mathbf{K}_{\mathbf{0 . 0 5 6}} \mathbf{M n O}_{\mathbf{2}}$. a XRD pattern and Rietveld refinement. Typical layered structure of $\mathrm{Na}_{0.612} \mathrm{~K}_{0.056} \mathrm{MnO}_{2}$ viewed along the $y$ axis $(\mathbf{b})$ and the $z$ axis (c) with $\mathrm{K}^{+}$located at the $\mathrm{Na}_{\mathrm{e}}$ sites. $\mathbf{d}$ PDF pattern and structure of $\mathrm{Na}_{0.612} \mathrm{~K}_{0.056} \mathrm{MnO}_{2}$. The representative peaks correspond to the bond length of $\mathrm{Mn}-\mathrm{O}$ (blue line) and $\mathrm{Mn}-\mathrm{Mn}$ (pale blue line) as labeled. e Fitting of $\mathrm{Mn}$ K-edge FT-EXAFS spectra of $\mathrm{Na}_{0.612} \mathrm{~K}_{0.056} \mathrm{MnO}_{2}$.
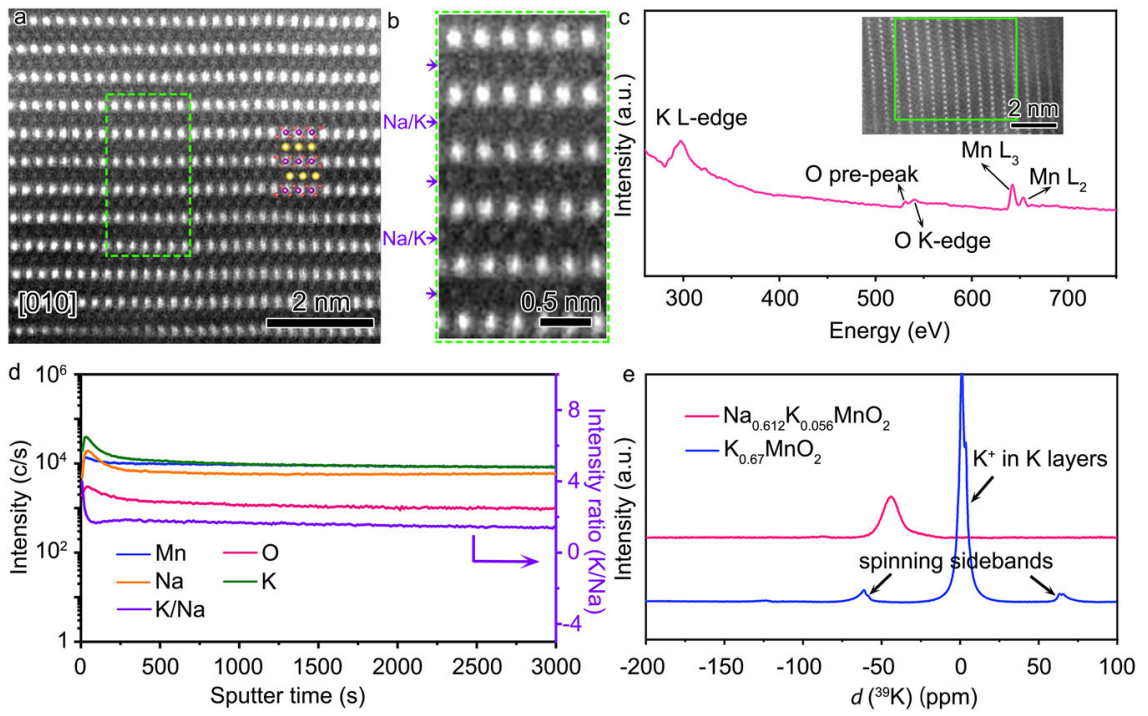

Fig. 2 Atomic structure and elemental distribution of $\mathbf{N a}_{\mathbf{0 . 6 1 2}} \mathbf{K}_{\mathbf{0 . 0 5 6}} \mathbf{M n O}_{\mathbf{2}}$. a STEM-HAADF image along the direction of [010] of $\mathrm{Na}_{0.612} \mathrm{~K}_{0.056} \mathrm{MnO}_{2}$. b Magnified images of the indicated squares in a. c EELS spectrum of the selected area in the inset image. $\mathbf{d}$ SIMS elemental profiles at different sputtering times. e Solid-state ${ }^{39} \mathrm{~K}$ NMR spectra of $\mathrm{Na}_{0.612} \mathrm{~K}_{0.056} \mathrm{MnO}_{2}$ and $\mathrm{K}_{0.67} \mathrm{MnO}_{2}$.

surface in the initial $50 \mathrm{~s}$ of sputtering, and then the intensity ratio of $\mathrm{K}$ and $\mathrm{Na}$ is gradually decreased to a stable value, indicating uniform distribution of $\mathrm{K}$ and $\mathrm{Na}$ in the bulk of $\mathrm{Na}_{0.612} \mathrm{~K}_{0.056} \mathrm{MnO}_{2}$. Similar trends for $\mathrm{Na}, \mathrm{Mn}$, and $\mathrm{O}$ are observed in the SIMS spectra of $\mathrm{Na}_{0.706} \mathrm{MnO}_{2}$ in Supplementary Fig. 14. Solid-state ${ }^{39} \mathrm{~K}$ nuclear magnetic resonance (NMR) spectrum of $\mathrm{Na}_{0.612} \mathrm{~K}_{0.056} \mathrm{MnO}_{2}$ with $\mathrm{K}_{0.67} \mathrm{MnO}_{2}$ as a reference is shown in Fig. 2e. The peak at $\sim 0 \mathrm{ppm}$ is assigned to $\mathrm{K}^{+}$located in the K-layers in the crystal structure of $\mathrm{K}_{0.67} \mathrm{MnO}_{2}$. The other two weak peaks at 70 and $-70 \mathrm{ppm}$ appear symmetrically and are assigned to the spinning sidebands due to the rotation of sample tube ${ }^{29}$. A negative chemical shift is observed for $\mathrm{Na}_{0.612} \mathrm{~K}_{0.056} \mathrm{MnO}_{2}$, which is attributed to the smaller electronic shielding effect of $\mathrm{Na}$ and $\mathrm{O}$ in $\mathrm{Na}_{0.612} \mathrm{~K}_{0.056} \mathrm{MnO}_{2}$ than $\mathrm{K}$ and $\mathrm{O}$ in $\mathrm{K}_{0.67} \mathrm{MnO}_{2}$, and a larger $d$-spacing of $0.64 \mathrm{~nm}$ in $\mathrm{K}_{0.67} \mathrm{MnO}_{2}$ than in $\mathrm{P} 2-\mathrm{Na}_{0.612} \mathrm{~K}_{0.056} \mathrm{MnO}_{2}$ with the similar layered structure, as shown in Supplementary Fig. 15 and Table 9 . These imply that $\mathrm{K}^{+}$exists only in the $\mathrm{Na}$ layer, not in the $\mathrm{MnO}_{2}$-layer, and has a uniform distribution in the bulk particles of $\mathrm{Na}_{0.612} \mathrm{~K}_{0.056} \mathrm{MnO}_{2}$.
Reaction mechanism. The structure evolution of $\mathrm{Na}_{0.612} \mathrm{~K}_{0.056} \mathrm{MnO}_{2}$ upon $\mathrm{Na}^{+}$extraction and intercalation is monitored by in situ XRD in a home-made battery within a voltage window of $1.8-4.3 \mathrm{~V}$. As shown in Fig. 3a, each XRD pattern is obtained during the battery operation and corresponding to the state as indicated in the charge and discharge curves in the right-hand panel. The pristine $\mathrm{Na}_{0.612} \mathrm{~K}_{0.056} \mathrm{MnO}_{2}$ is identified by the characteristic diffraction peaks of the (002), (004), (100), (102), and (104) planes in Fig. 3a. The P2 phase of $\mathrm{Na}_{0.612} \mathrm{~K}_{0.056} \mathrm{MnO}_{2}$ is sustained in the first charge process without phase transition, and $0.498 \mathrm{Na}^{+}$per formula is extracted to give the fully charged state (I) of $\mathrm{Na}_{0.114} \mathrm{~K}_{0.056} \mathrm{MnO}_{2}$, which agrees well with the ICP-OES in Supplementary Table 1. In the following discharge process, the $\mathrm{P} 2$ phase of the host is kept until $0.536 \mathrm{Na}^{+}$is inserted for $\mathrm{Na}_{0.65} \mathrm{~K}_{0.056} \mathrm{MnO}_{2}$ (II). Due to the slight distortion of the $\mathrm{MnO}_{6}$-octahedra slabs, the P'2 phase starts to appear with the coexistence of $\mathrm{P} 2$ phase, and becomes dominant in the fully discharged state (III) of $\mathrm{Na}_{1.015} \mathrm{~K}_{0.056} \mathrm{MnO}_{2}$. In the reverse charge process, the P'2 phase is gradually transformed to the P2 phase (IV), and then it is 


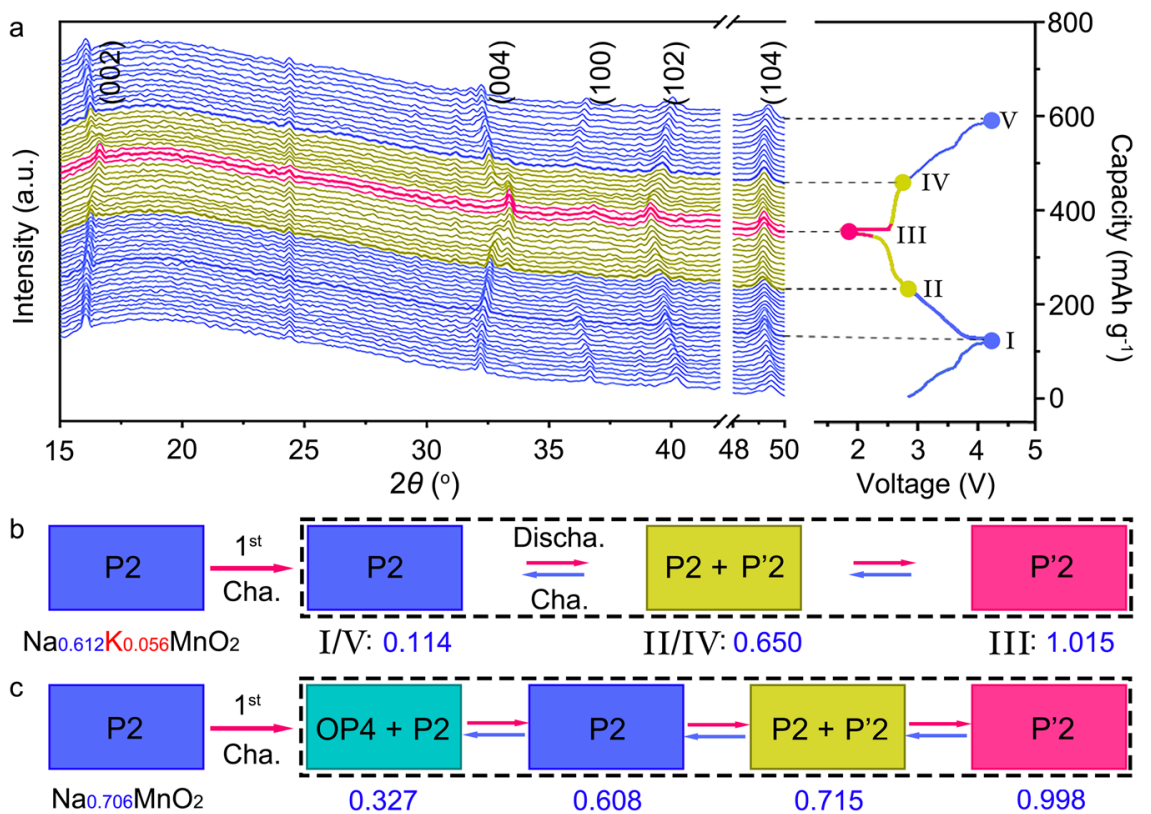

Fig. 3 Structure evolution during charge and discharge. a In situ XRD patterns corresponding to the charge and discharge curves of $\mathrm{Na}_{0.612} \mathrm{~K}_{0.056} \mathrm{MnO}_{2}$. Schematic illustration of phase transitions along with the content change of $\mathrm{Na}^{+}$in $\mathrm{Na}_{0.612} \mathrm{~K}_{0.056} \mathrm{MnO}_{2}$ (b) and $\mathrm{Na}_{0706} \mathrm{MnO}_{2}$ (c) in cycles of charge and discharge.

sustained at high charge voltages till $4.3 \mathrm{~V}$ (V). It involves the reversible two-phase transition of $\mathrm{P} 2 \leftrightarrow \mathrm{P}^{\prime} 2$ with total insertion or extraction of $0.901 \mathrm{Na}^{+}$in the cycles of discharge and charge, as schematically illustrated in Fig. 3b. In contrast, $\mathrm{P} 2-\mathrm{Na}_{0.706} \mathrm{MnO}_{2}$ involves large gliding of the $\mathrm{MnO}_{6}$-octahedra slabs for the phase transition of $\mathrm{P} 2 \rightarrow \mathrm{OP} 4$ upon extraction of $0.455 \mathrm{Na}^{+}$at high charge voltages; it then converts from the $\mathrm{OP} 4$ phase into $\mathrm{P} 2$ and $\mathrm{P}^{\prime} 2$ during discharge with total insertion or extraction of $0.671 \mathrm{Na}^{+}$in cycles, as shown in the schematic phase transitions of $\mathrm{P} 2-\mathrm{Na}_{0.706} \mathrm{MnO}_{2}$ in Fig. $3 \mathrm{c}$ and in situ XRD patterns in Supplementary Fig. 17. Rietveld refinements of the fully charged and discharged $\mathrm{Na}_{0.612} \mathrm{~K}_{0.056} \mathrm{MnO}_{2}$ and $\mathrm{P} 2-\mathrm{Na}_{0.706} \mathrm{MnO}_{2}$ (Supplementary Figs. 18-21 and Supplementary Tables 10-13) show drastic changes in the crystal structure and lattice parameters of $\mathrm{P} 2-\mathrm{Na}_{0.706} \mathrm{MnO}_{2}$. It was found that the volume variation of $\mathrm{Na}_{x} \mathrm{~K}_{0.065} \mathrm{MnO}_{2}$ is $7.8 \%$, which is significantly smaller than $11.2 \%$ in $\mathrm{Na}_{x} \mathrm{MnO}_{2}$, and favors the structural stability during cycling. It reveals that more $\mathrm{Na}^{+}\left(0.901\right.$ vs. $\left.0.671 \mathrm{Na}^{+}\right)$can be extracted at the high charge voltages and re-inserted from/into P2$\mathrm{Na}_{0.612} \mathrm{~K}_{0.056} \mathrm{MnO}_{2}$ than $\mathrm{P} 2-\mathrm{Na}_{0.706} \mathrm{MnO}_{2}$, due to the reduced $\mathrm{Na}-\mathrm{O}$ bond strength and reinforced $\mathrm{MnO}_{6}$-octahedra slabs for suppression of the inferior OP4 phase.

The redox of $\mathrm{Na}_{0.612} \mathrm{~K}_{0.056} \mathrm{MnO}_{2}$ is further unveiled by $\mathrm{X}$-ray photoelectron spectroscopy (XPS) and EELS. The XPS Mn $2 p$ spectrum of $\mathrm{Na}_{0.612} \mathrm{~K}_{0.056} \mathrm{MnO}_{2}$ in Fig. $4 \mathrm{a}$ shows the splitting $\mathrm{Mn}$ $2 p_{3 / 2}$ and $\mathrm{Mn} 2 p_{1 / 2}$ at $640.8 / 642.2$ and $652.4 / 654.9 \mathrm{eV}$, respectively, suggesting the co-existence of $\mathrm{Mn}^{3+}$ and $\mathrm{Mn}^{4+}$ with a ratio of 2:1. Upon charging, the intensity of $\mathrm{Mn}^{4+}$ peaks increases with decrease of the intensity of $\mathrm{Mn}^{3+}$ peaks, indicating oxidation of $\mathrm{Mn}^{3+}$ to $\mathrm{Mn}^{4+}$ in Fig. 4a. The remaining $\mathrm{Mn}^{3+}$ is 0.08 per formula at the charge finish of $4.3 \mathrm{~V}$, which is consistent with the phase transition in Fig. 3b. The reduction of $\mathrm{Mn}^{4+}$ to $\mathrm{Mn}^{3+}$ in the following discharge process is evidenced by the gradual intensity increase of $\mathrm{Mn}^{3+}$ peaks till the disappearance of $\mathrm{Mn}^{4+}$ peaks, as shown in Fig. 4b. The peaks at $646.5 \mathrm{eV}$ in Fig. $4 \mathrm{a}$, b are mainly attributed to Augers of $\mathrm{C}-\mathrm{F}$ and $\mathrm{Na}-\mathrm{F}^{30}$. In addition, the EELS spectra of the charged, discharged, and pristine states of $\mathrm{Na}_{0.612} \mathrm{~K}_{0.056} \mathrm{MnO}_{2}$ in Fig. $4 \mathrm{c}$ further confirm the redox of $\mathrm{Mn}^{3}$ $+/ \mathrm{Mn}^{4+}$ with the reversible shifts of the two peaks of $\mathrm{Mn}-\mathrm{L}_{2}$ and
$\mathrm{Mn}-\mathrm{L}_{3}$. It is notable that there is no peak shift or broadening in both of the $\mathrm{O}$ pre-peak and $\mathrm{K}$-edge, which suggests no valence change of $\mathrm{O}^{2-}$. Therefore, the redox of $\mathrm{Mn}^{3+} / \mathrm{Mn}^{4+}$ is responsible for the charge compensation in the extraction and reinsertion of $\mathrm{Na}^{+}$from/into $\mathrm{Na}_{0.612} \mathrm{~K}_{0.056} \mathrm{MnO}_{2}$ in the discharge and charge processes. Also, no oxygen evolution was detected by in situ differential electrochemical mass spectrometry (DEMS) in the charge process (Supplementary Fig. 22).

Density functional theory (DFT) calculations using Vienna Abinitio Simulation Package (VASP) are performed to optimize the crystal structures of the pristine and charged cathode materials ${ }^{31-34}$. Because the numbers of $\mathrm{K}$ and $\mathrm{Na}$ atoms can only be integral in a unit cell, there exists a slight difference between the simulated formula and the obtained composition, which can be reasonably ignored. Figure 5a and Supplementary Fig. 23 exhibit the first-principle molecular dynamics simulations of $\mathrm{Na}_{0.500} \mathrm{~K}_{0.055} \mathrm{MnO}_{2}$ and $\mathrm{Na}_{0.555} \mathrm{MnO}_{2}$, respectively, where the mean square displacements (MSDs) from 0 to 5 ps reflect the diffusion capability of each element. It shows that $\mathrm{Na}^{+}$is more facile to migrate in $\mathrm{Na}_{0.500} \mathrm{~K}_{0.055} \mathrm{MnO}_{2}$, and $\mathrm{K}^{+}$is immobile as riveted between layers. Its migration is energetically unfavorable as displayed in Supplementary Fig. 24, in which its migration energy barrier is as high as $\sim 0.8 \mathrm{eV}$ in contrast with $\sim 0.4 \mathrm{eV}$ for $\mathrm{Na}^{+}$in $\mathrm{Na}_{0.500} \mathrm{~K}_{0.055} \mathrm{MnO}_{2}$ (refs. ${ }^{35-37}$ ). Its diffusion coefficient is accordingly five orders of magnitude lower than that of $\mathrm{Na}^{+}$ based on Arrhenius equation. This is consistent with ICP-OES and elemental mappings in Supplementary Table 1 and Figs. 25 and 26, in which the content of $\mathrm{K}$ remains almost constant, suggesting no $\mathrm{K}$ loss in the charge and discharge processes. The optimized $\mathrm{Na}_{0.500} \mathrm{~K}_{0.055} \mathrm{MnO}_{2}$ in Supplementary Fig. 27a shows a pure $\mathrm{P} 2$ phase with $\mathrm{K}^{+}$located in the $\mathrm{Na}$ layers. It can be sustained in the optimized structure of $\mathrm{P} 2-\mathrm{Na}_{0.220} \mathrm{~K}_{0.055} \mathrm{MnO}_{2}$ at the fully charged state with similar structure parameters in Supplementary Fig. 27b. This indicates the significant role of $\mathrm{K}$ for the stabilization of the crystal structure of $\mathrm{Na}_{0.612} \mathrm{~K}_{0.056} \mathrm{MnO}_{2}$ for extraction and insertion of $\mathrm{Na}^{+}$. It is robust to allow for the extraction of $0.498 \mathrm{Na}^{+}$in the first charge without phase transition, as depicted in Fig. 3. 

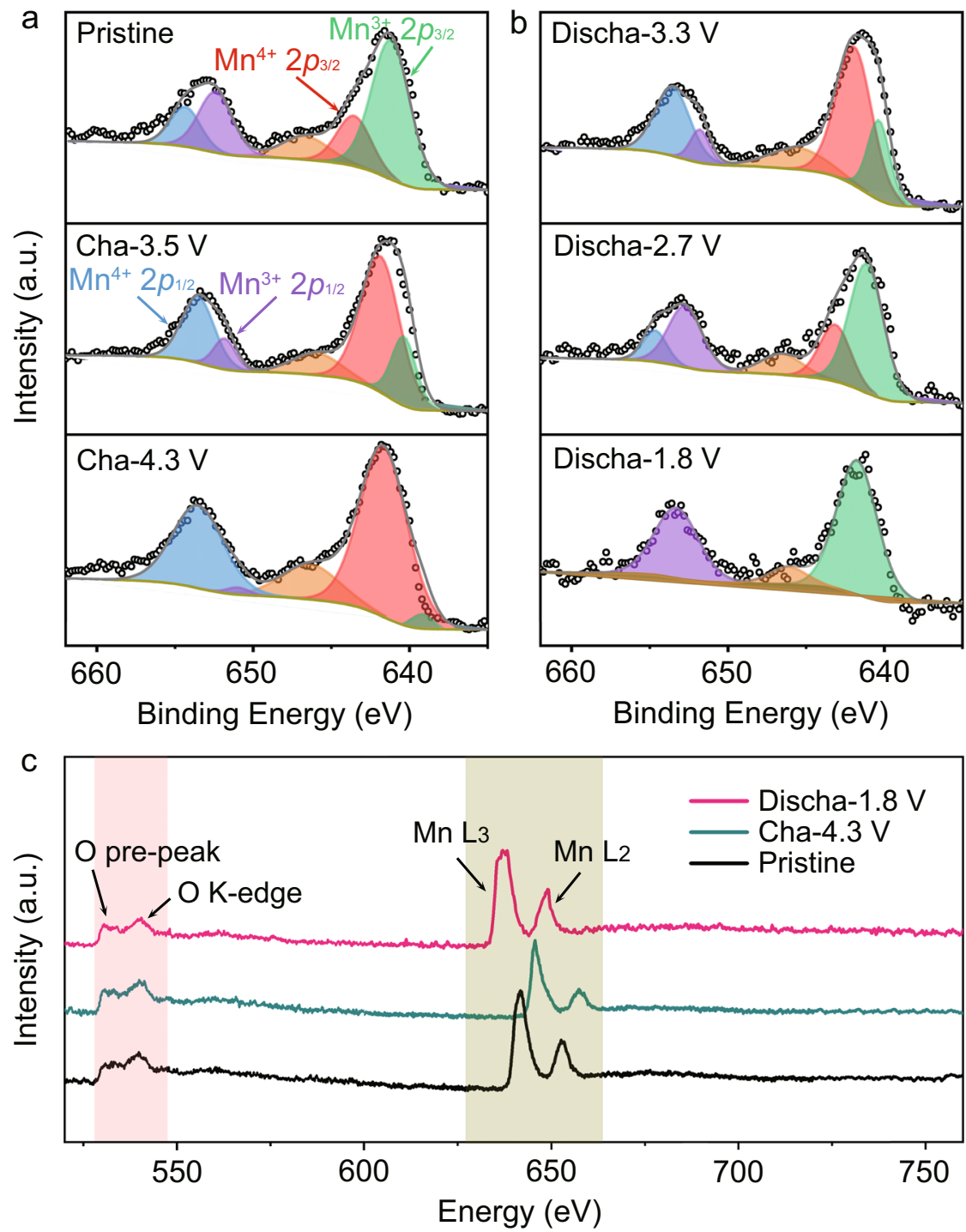

Fig. 4 Valence evolution during charge and discharge of $\mathbf{N a}_{\mathbf{0 . 6 1 2}} \mathbf{K}_{\mathbf{0 . 0 5 6}} \mathbf{M n O}_{\mathbf{2}}$. XPS Mn $2 p$ spectra at the charge (a) and discharge (b) states. c EELS spectra at different states of $\mathrm{Na}_{0.612} \mathrm{~K}_{0.056} \mathrm{MnO}_{2}$.

The electronic structures of $\mathrm{Na}_{0.500} \mathrm{~K}_{0.055} \mathrm{MnO}_{2}$ and $\mathrm{Na}_{0.555} \mathrm{MnO}_{2}$ have been investigated by DFT calculations. As shown in the density of states (DOS) of $\mathrm{Na}_{0.220} \mathrm{~K}_{0.055} \mathrm{MnO}_{2}$ in Fig. 5b, although $\mathrm{K}$ only accounts for one fourth of $\mathrm{Na}$ in the composition, the DOS contributed by $\mathrm{K}$ atoms is similar to that of $\mathrm{Na}$ atoms. In addition, the partial charge density distribution in Fig. $5 \mathrm{c}$ reflects the local status of electrons. The electron cloud overlap between $\mathrm{K}$ and $\mathrm{O}$ is stronger than that between $\mathrm{Na}$ and $\mathrm{O}$. As seen from the deformation charge densities for $\mathrm{Na}_{0.500} \mathrm{~K}_{0.055} \mathrm{MnO}_{2}$ in Fig. 5d, the electron population at $\mathrm{O}$ atoms increases. However, the crystal orbital Hamilton populations (COHP) in Supplementary Fig. 28 indicate that it falls in a K-O antibonding region around the Fermi level, which is different from the bonding area of $\mathrm{Na}-\mathrm{O}$ in $\mathrm{Na}_{0.55} \mathrm{MnO}_{2}$. Schematic pDOS of $\mathrm{Na}_{0.500} \mathrm{~K}_{0.055} \mathrm{MnO}_{2}$ and $\mathrm{Na}_{0.555} \mathrm{MnO}_{2}$ are shown in Fig. 5e and Supplementary Figs. 29 and 30. The increased spindown electrons around Fermi energy indicate stronger hybridization interaction between $\mathrm{Mn}$ and $\mathrm{O}$ in the presence of $\mathrm{K}^{+}$, in good agreement with the analysis of FT-EXAFS in Fig. 1d. Also, the Na-O bond strength in $\mathrm{Na}_{0.500} \mathrm{~K}_{0.055} \mathrm{MnO}_{2}$ is found to be reduced by COHP analysis in Supplementary Table 14. As indicated by COHP analysis in Fig. $5 f$ and Supplementary Tables 15-17, the Mn-O bonds are reinforced for both adjacent and distant $\mathrm{Mn}$ atoms with a more obvious increase in $x y$-plane by the substitution of $\mathrm{K}$. A slight fluctuation of $\mathrm{Mn}-\mathrm{O}$ bond strength is found for different valence state of $\mathrm{Mn}$. These lead to more thermodynamically favorable $\mathrm{Na}^{+}$ vacancies (Supplementary Table 18), which is the determining factor for $\mathrm{Na}^{+}$extraction and insertion, consistent with MSD in Fig. 5a. Of note, the formation energy for $\mathrm{K}^{+}$siting in the $\mathrm{Na}_{\mathrm{e}}$ site $(0.675 \mathrm{eV})$ is higher than in the $\mathrm{Na}_{\mathrm{f}}$ site $(-3.500 \mathrm{eV})$ of $\mathrm{Na}_{0.500} \mathrm{~K}_{0.055} \mathrm{MnO}_{2}$, which indicates the higher thermodynamic stability of the $\mathrm{Na}_{\mathrm{e}}$ site for $\mathrm{K}^{+}$. Furthermore, the reinforced Mn-O bonds play an important role to suppress the phase transition during $\mathrm{Na}^{+}$extraction and insertion and favor the cycle stability.

Electrochemical performance. The electrochemical performance of $\mathrm{Na}_{0.612} \mathrm{~K}_{0.056} \mathrm{MnO}_{2}$ is evaluated against $\mathrm{Na}$ metal anodes with the electrolyte of $1.0 \mathrm{M} \mathrm{NaPF}_{6}$ in propylene carbonate (PC) and $5 \mathrm{wt} . \%$ of fluoroethylene carbonate (FEC) in coin cells. Figure 6a exhibits the typical charge and discharge profiles of $\mathrm{Na}_{0.612} \mathrm{~K}_{0.056} \mathrm{MnO}_{2}$ and $\mathrm{Na}_{0.706} \mathrm{MnO}_{2}$ at $20 \mathrm{~mA} \mathrm{~g}^{-1}$. $\mathrm{Na}_{0.612} \mathrm{~K}_{0.056} \mathrm{MnO}_{2}$ delivers a high initial charge capacity of $125.1 \mathrm{mAh} \mathrm{g}^{-1}$, corresponding to $0.498 \mathrm{Na}^{+}$per formula. In the following cycles, the reversible capacity of $\mathrm{Na}_{0.612} \mathrm{~K}_{0.056} \mathrm{MnO}_{2}$ reaches up to $240.5 \mathrm{mAh} \mathrm{g}^{-1}$, which is much 

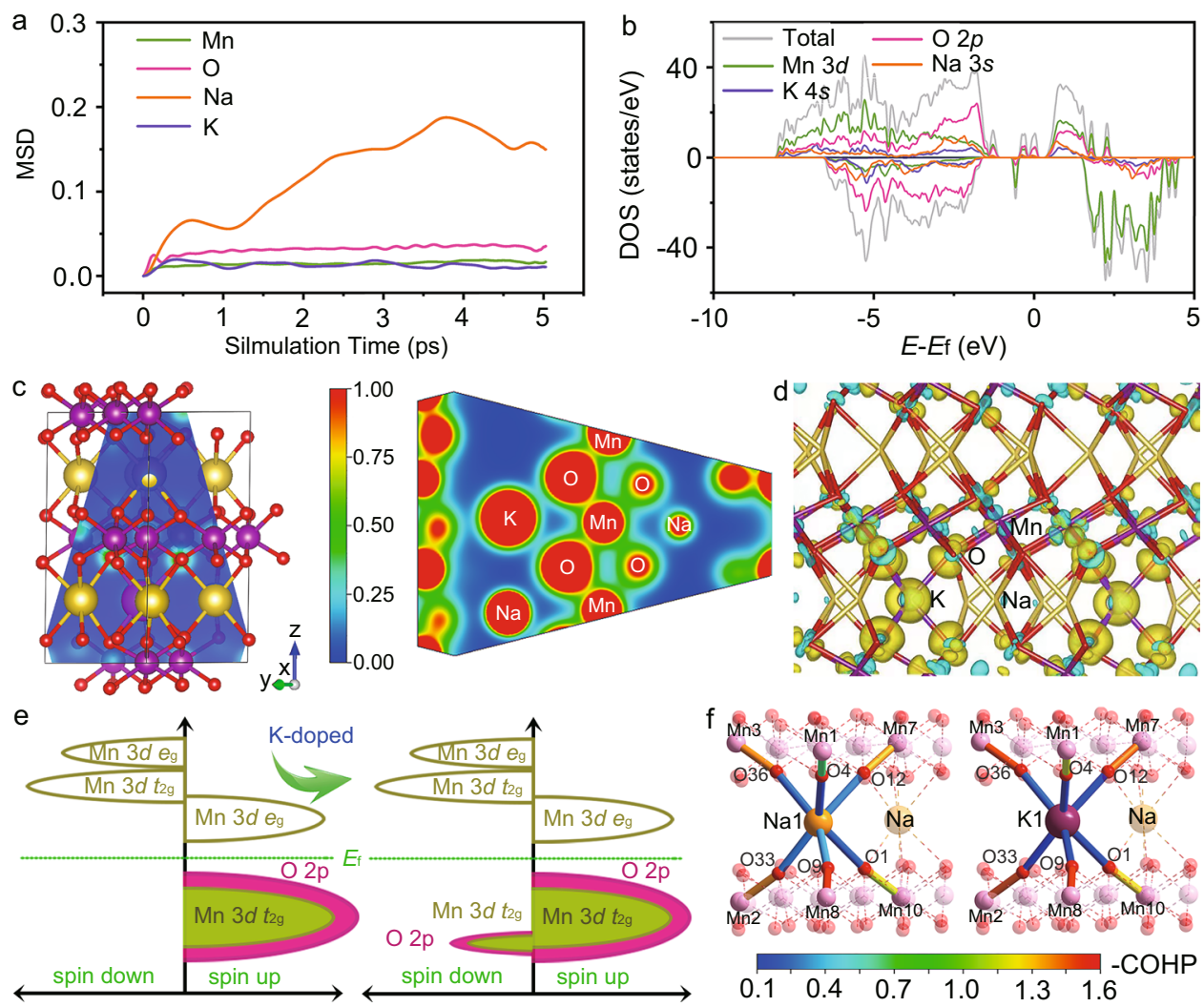

Fig. 5 Simulated atomic and electronic structures. a MSD of $\mathrm{Mn}, \mathrm{K}, \mathrm{Na}$, and $\mathrm{O}$ as functions of time in $\mathrm{Na}_{0.500} \mathrm{~K}_{0.055} \mathrm{MnO}_{2}$. b Total density of states (tDOS) of $\mathrm{Na}_{0.220} \mathrm{~K}_{0.055} \mathrm{MnO}_{2}$ and partial density of states (pDOS) of $\mathrm{Na} 3 \mathrm{~s}, \mathrm{~K} 4 \mathrm{~s}, \mathrm{O} 2 \mathrm{p}$ and $\mathrm{Mn} 3 d$ orbitals, as labeled by yellow, purple, red and green, respectively. The Fermi energy $\left(E_{\mathrm{f}}\right)$ is set to $\mathrm{OeV}$, and the pDOS of $\mathrm{Na} 3 \mathrm{~s}, \mathrm{~K} 4 \mathrm{~s}$ are enlarged by 100 times. $\mathrm{c}$ Partial charge density distribution along the blue plane in the left panel for $\mathrm{Na}_{0.500} \mathrm{~K}_{0.055} \mathrm{MnO}_{2}$ (visualized by Visualization for Electronic and Structure Analysis (VESTA)). The red regions represent high charge density, and the blue regions indicate low charge density. d Plot of deformation charge densities of $\mathrm{Na}_{0.500} \mathrm{~K}_{0.055} \mathrm{MnO}_{2}$. The charge accumulation region is rendered in yellow, and the charge depletion is in blue. e Schematic pDOS of $\mathrm{Na}_{0.555} \mathrm{MnO}_{2}$ and $\mathrm{Na}_{0.500} \mathrm{~K}_{0.055} \mathrm{MnO}_{2}$. $\mathbf{f} \mathrm{COHP}$ analysis on representative prismatic sites and the adjacent $\mathrm{MnO}_{6}$-octahedra sites of $\mathrm{Na}_{0.555} \mathrm{MnO}_{2}$ and $\mathrm{Na}_{0.500} \mathrm{~K}_{0.055} \mathrm{MnO}_{2}$.

higher than that of $\mathrm{Na}_{0.706} \mathrm{MnO}_{2}\left(167.2 \mathrm{mAh} \mathrm{g}^{-1}\right)$. This means that $0.901 \mathrm{Na}^{+}$per formula is inserted and extracted into/from $\mathrm{Na}_{0.612} \mathrm{~K}_{0.056} \mathrm{MnO}_{2}$. It agrees well with the restricted phase transition in Fig. 3. At the same time, $\mathrm{Na}_{0.612} \mathrm{~K}_{0.056} \mathrm{MnO}_{2}$ presents higher discharge voltages than $\mathrm{Na}_{0.706} \mathrm{MnO}_{2}$ does, which is consistent with the cyclic voltammetry $(\mathrm{CV})$ curves in Supplementary Fig. 31. The energy density of $\mathrm{Na}_{0.612} \mathrm{~K}_{0.056} \mathrm{MnO}_{2}$ is as high as $654 \mathrm{Wh} \mathrm{kg}^{-1}$, in comparison with the reported cathode materials in Fig. 6b. Of particular, it is even higher than that of $\mathrm{Na}_{0.72} \mathrm{Li}_{0.24} \mathrm{Mn}_{0.76} \mathrm{O}_{2}$, which works with both the $\mathrm{O}$ redox and $\mathrm{Mn}^{3+} / \mathrm{Mn}^{4+}$ to deliver the highest specific capacity in refs. ${ }^{38-45}$.

The cycle stability of $\mathrm{Na}_{0.612} \mathrm{~K}_{0.056} \mathrm{MnO}_{2}$ is tested at $50 \mathrm{~mA} \mathrm{~g}^{-1}$, and the selected charge/discharge profiles of the 1st, 5th, 10th, and 100th cycles are presented in Supplementary Fig. 32. Except for the 1st charge, the charge/discharge profiles are almost overlapped. The capacity after 100 cycles is sustained for 236.2 $\mathrm{mAh} \mathrm{g}^{-1}$, corresponding to capacity retention of $98.2 \%$ with only $0.018 \%$ loss per cycle in Fig. $6 \mathrm{c}$, which is highly contrasting with the fluctuating capacities of $\mathrm{Na}_{0.706} \mathrm{MnO}_{2}$. This implies that the structure of $\mathrm{Na}_{0.612} \mathrm{~K}_{0.056} \mathrm{MnO}_{2}$ is robust upon extraction and insertion of $\mathrm{Na}^{+}$in cycles, as confirmed by in situ XRD in Fig. 3.

The $\mathrm{Na}^{+}$diffusion coefficients are estimated by Galvanostatic intermittent titration technique (GITT) in Supplementary Figs. 33-37. The obtained diffusion coefficients $\left(D_{\mathrm{Na}}+\right)$ for the single-phase regions of both $\mathrm{Na}_{x} \mathrm{~K}_{0.056} \mathrm{MnO}_{2}$ and $\mathrm{Na}_{x} \mathrm{MnO}_{2}$ are in the range of $10^{-12}-10^{-10} \mathrm{~cm}^{2} \mathrm{~s}^{-1}$, and they exhibit decreasing trends as the sodiation proceeds near the two-phase regions in Fig. 6d and Supplementary Fig. 38. Because the GITT method cannot be applicable to the two-phase regions, CVs at different scan rates are used to calculate the apparent values of $D_{\mathrm{Na}}$ in $\mathrm{Na}_{0.612} \mathrm{~K}_{0.056} \mathrm{MnO}_{2}$ and $\mathrm{Na}_{0.706} \mathrm{MnO}_{2}$, as presented in the gray region in Fig. 6d, Supplementary Fig. 39, and Supplementary Table 19. $\mathrm{Na}_{0.612} \mathrm{~K}_{0.056} \mathrm{MnO}_{2}$ exhibits faster $\mathrm{Na}^{+}$transport with the content change of $\mathrm{Na}$ during charge and discharge, though there is $\mathrm{K}^{+}$riveted between the layers. Enhanced rate capability is presented in $\mathrm{Na}_{0.612} \mathrm{~K}_{0.056} \mathrm{MnO}_{2}$ in Supplementary Fig. 40, in which the reversible capacities are kept from $238.8 \mathrm{mAh} \mathrm{g}^{-1}$ to 211.6 and $110.2 \mathrm{mAh} \mathrm{g}^{-1}$ at the currents from $50 \mathrm{~mA} \mathrm{~g}^{-1}$ to 100 and $2000 \mathrm{~mA} \mathrm{~g}^{-1}$, respectively. The demonstrated good cycle performance and rate capability of $\mathrm{Na}_{0.612} \mathrm{~K}_{0.056} \mathrm{MnO}_{2}$ are attributed to the reinforced structure stability and facile $\mathrm{Na}^{+}$ transport.

A full battery with $\mathrm{P} 2-\mathrm{Na}_{0.612} \mathrm{~K}_{0.056} \mathrm{MnO}_{2}$ cathode and presodiated hard carbon (HC) anode was demonstrated. The performance of $\mathrm{HC}$ anode was firstly investigated in half battery in Supplementary Fig. 41a. As displayed in Fig. 6e, a pair of redox peaks appear at $0.036 / 0.113 \mathrm{~V}$ for $\mathrm{HC}$ anode, and the obtained peaks of the full battery are similar to those of $\mathrm{Na}_{0.612} \mathrm{~K}_{0.056} \mathrm{MnO}_{2}$, implying reversible electrochemical reactions. The full battery delivers a specific capacity of $230.6 \mathrm{mAh} \mathrm{g}^{-1}$ based on the mass of active cathode material at $50 \mathrm{~mA} \mathrm{~g}^{-1}$ in Fig. $6 \mathrm{f}$, corresponding to a high energy density of $314.4 \mathrm{Wh} \mathrm{kg}^{-1}$ based on the total mass of active anode and cathode materials. It also exhibits good cycling stability and rate performance in Supplementary Fig. 41. The electrochemical performance can be optimized by selecting high efficient $\mathrm{HC}$ and $\mathrm{Na}$ compensation method. This implies 

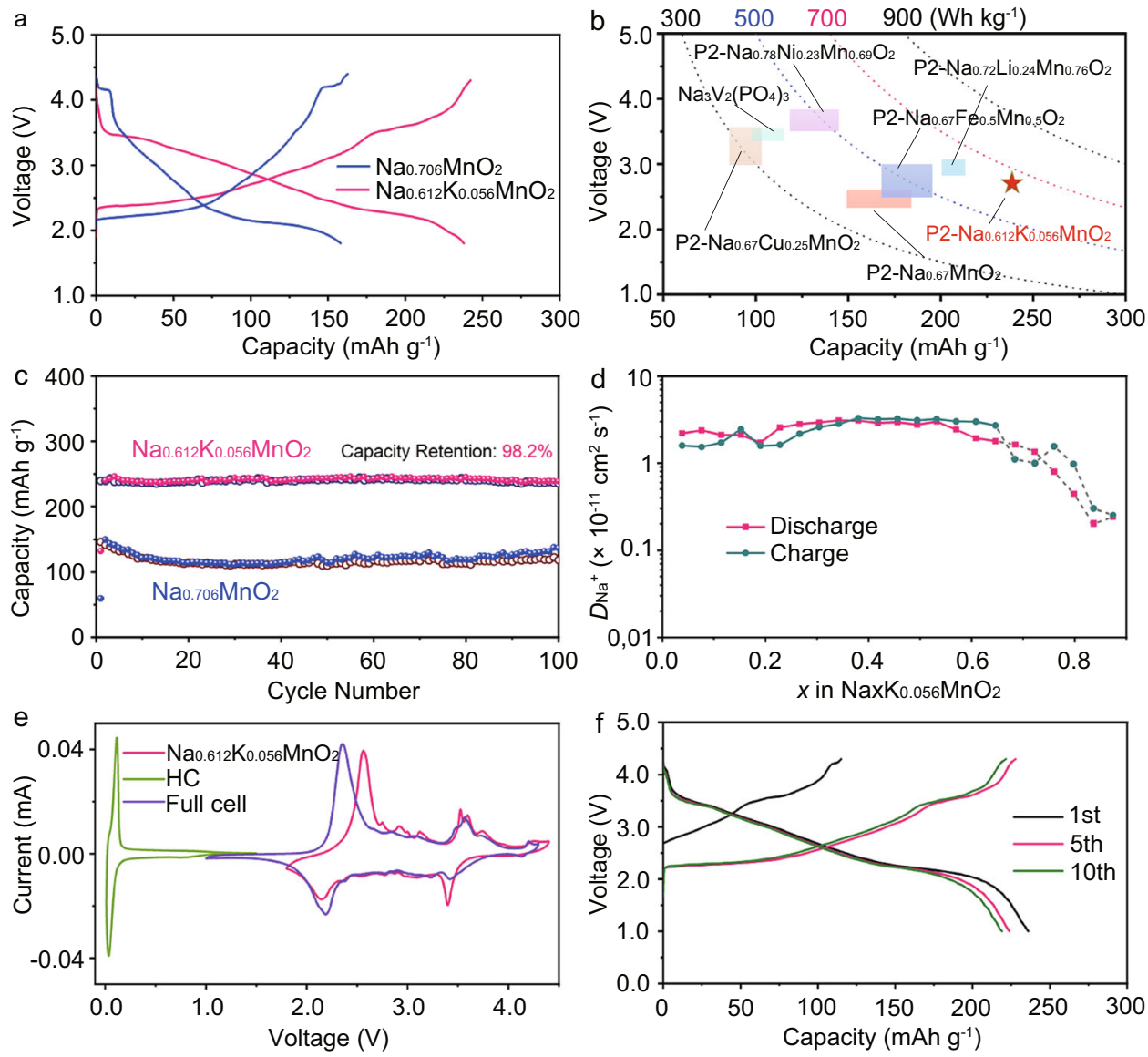

Fig. 6 Electrochemical performance. a Typical charge/discharge curves of $\mathrm{Na}_{0.612} \mathrm{~K}_{0.056} \mathrm{MnO}_{2}$ and $\mathrm{Na}_{0.706} \mathrm{MnO}_{2}$ at $20 \mathrm{~mA} \mathrm{~g}{ }^{-1}$ in the third cycle. b Comparison of energy density and average voltages of $\mathrm{Na}_{0.612} \mathrm{~K}_{0.056} \mathrm{MnO}_{2}$ with typical cathode materials in refs. ${ }^{38-45}$. c Cycle performance of $\mathrm{Na}_{0.612} \mathrm{~K}_{0.056} \mathrm{MnO}_{2}$ and $\mathrm{Na}_{0.706} \mathrm{MnO}_{2}$ at $50 \mathrm{~mA} \mathrm{~g}{ }^{-1}$. d Variation of $D_{\mathrm{Na}}+$ as functions of $\mathrm{x}$ in $\mathrm{Na}_{x} \mathrm{~K}_{0.056} \mathrm{MnO}_{2}$ determined by GITT and CV, where the gray dotted area represents the two-phase region. e CV curves of $\mathrm{Na}_{0.612} \mathrm{~K}_{0.056} \mathrm{MnO}_{2}, \mathrm{HC}$ and the full battery of $\mathrm{HC} / / \mathrm{Na}_{0.612} \mathrm{~K}_{0.056} \mathrm{MnO}_{2}$ at $0.1 \mathrm{mV} \mathrm{s}^{-1}$. f Typical charge/discharge curves of $\mathrm{HC} / / \mathrm{Na}_{0.612} \mathrm{~K}_{0.056} \mathrm{MnO}_{2}$ at $50 \mathrm{mAg}^{-1}$.

that $\mathrm{P} 2-\mathrm{Na}_{0.612} \mathrm{~K}_{0.056} \mathrm{MnO}_{2}$ will be of great potential for the highperformance SIBs.

In summary, a cathode material of $\mathrm{P} 2-\mathrm{Na}_{0.612} \mathrm{~K}_{0.056} \mathrm{MnO}_{2}$ has been successfully obtained with the $\mathrm{K}^{+}$riveted in the prismatic edge-sharing sites of $\mathrm{Na}_{\mathrm{e}}$ between the $\mathrm{MnO}_{6}$-octahedra slabs. The reinforced $\mathrm{MnO}_{6}$-octahedra slabs and reduced $\mathrm{Na}^{+}$vacancy formation energy enable more active $\mathrm{Na}^{+}$sites and favor its facile diffusion. This leads to the highest reversible capacity of $240.5 \mathrm{mAh} \mathrm{g}^{-1}$, corresponding to $0.901 \mathrm{Na}^{+}$per formula, and energy density of $654 \mathrm{Wh} \mathrm{kg}^{-1}$ based on the redox of $\mathrm{Mn}^{3+} / \mathrm{Mn}^{4+}$ among the reported transition-metal oxide cathodes for SIBs, and good capacity retention of $98.2 \%$ after 100 cycles. The reinforced interaction in the $\mathrm{MnO}_{6}$-octahedra slabs restricts the layer gliding and ensures the robust crystal structure of $\mathrm{P} 2-\mathrm{Na}_{0.612} \mathrm{~K}_{0.056} \mathrm{MnO}_{2}$, in which two-phase transition of P2 $\leftrightarrow$ P'2 occurs only at low charge and discharge voltages, favoring the structure stability and cycle performance. This strategy to finely tune the local chemistry for high energy density and long cycle life will shed lights into the design of electrode materials for SIBs and beyond.

\section{Methods}

Materials synthesis. $\mathrm{P} 2-\mathrm{Na}_{0.67-x} \mathrm{~K}_{x} \mathrm{MnO}_{2}$ was synthesized via a solid-state reaction. For the synthesis of $\mathrm{Na}_{0.612} \mathrm{~K}_{0.056} \mathrm{MnO}_{2}, \mathrm{NaCH}_{3} \mathrm{COOH}$ (99\%, Alfa, $12.54 \mathrm{mmol}, 10 \%$ in excess), $\mathrm{K}_{2} \mathrm{CO}_{3}$ (99\%, Alfa, $2.1 \mathrm{mmol}, 5 \%$ in excess), and $\mathrm{MnO}_{2}(99 \%$, Alfa, $20 \mathrm{mmol})$ were mixed in a planetary ball mill (QM-3SP2) at $400 \mathrm{rpm}$ for $12 \mathrm{~h}$ in the presence of a small amount of acetone. The as-synthesized precursors were dried at $80^{\circ} \mathrm{C}$ for $12 \mathrm{~h}$, and then pressed into a pallet under $20 \mathrm{MPa}$. It was heated at $500{ }^{\circ} \mathrm{C}$ for $2 \mathrm{~h}$ and $900^{\circ} \mathrm{C}$ for $10 \mathrm{~h}$ in air at $5{ }^{\circ} \mathrm{C} / \mathrm{min}$.
Then, it was cooled down to $200{ }^{\circ} \mathrm{C}$ at $5{ }^{\circ} \mathrm{C} / \mathrm{min}$ and naturally to room temperature, and stored in an argon-filled glovebox. Similar processes were applicable to the synthesis of $\mathrm{Na}_{0.706} \mathrm{MnO}_{2}$ except the addition of $\mathrm{K}_{2} \mathrm{CO}_{3}$.

Electrochemical measurements. Coin cells (CR2032) were assembled in an argon-filled glovebox for all the electrochemical tests. The working electrode was prepared by coating the mixture of active material ( $80 \mathrm{wt} . \%)$, Super P (10 wt.\%), and polytetrafluoroethylene (10 wt.\%) in $\mathrm{N}$-methyl-2-pyrrolidone onto an $\mathrm{Al}$ foil. The loading mass of active material in each electrode pellet of $12.0 \mathrm{~mm}$ in diameter was $\sim 3.0 \mathrm{mg} \mathrm{cm}^{-2}$. For half battery, sodium foil was used as the anode, and $1.0 \mathrm{M}$ $\mathrm{NaPF}_{6}$ in PC containing 5 wt.\% of FEC was employed as the electrolyte with glass fiber filter papers as the separator. The charge/discharge tests and Galvanostatic intermittent titration technique (GITT) were carried out on a Land CT2001A battery test system (Land, Wuhan, China) in a voltage range of $1.8-4.3 \mathrm{~V}$ at $25^{\circ} \mathrm{C}$. GITT was measured by applying the repeated current pulses for $30 \mathrm{~min}$ at a current density of $10 \mathrm{~mA} \mathrm{~g}^{-1}$, followed by relaxation for $1.5 \mathrm{~h}$. CV experiments were performed within the same potential range at $0.1 \mathrm{mV} \mathrm{s}^{-1}$. CV was carried out on a Solartron $1470 \mathrm{E}$ electrochemical workstation in a voltage range of $1.8-4.3 \mathrm{~V}$. The full battery was assembled with $\mathrm{P} 2-\mathrm{Na}_{0.612} \mathrm{~K}_{0.056} \mathrm{MnO}_{2}$ as the cathode, $\mathrm{HC}$ as the anode, and $1.0 \mathrm{M} \mathrm{NaPF}_{6}$ in $\mathrm{PC}$ containing 5 wt.\% of $\mathrm{FEC}$ as the electrolyte, respectively. In order to supplement sufficient $\mathrm{Na}^{+}$in $\mathrm{HC}$ before assembling full battery, the $\mathrm{HC}$ electrode was obtained by disassembling the half battery in the glove box after half-discharging at $50 \mathrm{~mA} \mathrm{~g}^{-1}$. The mass ratio of

$\mathrm{Na}_{0.612} \mathrm{~K}_{0.056} \mathrm{MnO}_{2} / \mathrm{HC}$ is around 1.2 , corresponding to $4 \%$ excess of anode capacity. The charge/discharge and $\mathrm{CV}$ tests were carried out at $25^{\circ} \mathrm{C}$ in a voltage range of $1.0-4.3 \mathrm{~V}$.

Material characterizations. The chemical composition of the electrodes was determined by an inductively coupled plasma-optical emission spectrometer (ICPOES, SPECTRO-BLUE). XRD was collected on Rigaku SmartLab equipped with a $\mathrm{Cu} \mathrm{Ka}$ radiation source. Rietveld refinement was conducted with the Fullprof software ${ }^{46}$. The PDF analysis was carried out based on X-ray scattering data 
measured at the 11-ID-B beamline of the Advanced Photon Source at Argonne National Laboratory. High energy X-rays $(\lambda=0.1173 \AA$ ) were used to collect data to high values of momentum transfer $\left(Q \sim 30 \AA^{-1}\right)$. Diffraction images were integrated within fit2D to obtain one-dimensional diffraction data ${ }^{47}$. Pair distribution functions, $G(\mathrm{r})$, were extracted from the data within PDFgetX $3^{48}$, after correcting for background and Compton scattering. Mn K-edge X-ray absorption fine structure (XAFS) results were collected at the beamline 8C in Pohang Accelerator Laboratory (PAL). The XAFS data were collected by fluorescence mode and processed through Demeter software package ${ }^{49}$. The extended $\mathrm{x}$-ray absorption fine structure (EXAFS) region was $k^{3}$ weighted and Fourier-transformed in $k$ ranges of 3.0-10.0 $\AA^{-1}$. Schematic representations of the synthesized samples were obtained by using the VESTA software ${ }^{50}$. The morphology was examined by SEM (JEOL JSM-7500F, AEMC, $5 \mathrm{kV}$ ). The HRTEM images, SAED patterns and EDS mappings were recorded by TEM (FEI Taosl F200X G2, AEMC, $200 \mathrm{kV}$ ). HAADF and $\mathrm{ABF}$ images were obtained on a JEM-AR200F STEM with an accelerating voltage of $200 \mathrm{kV}$ with cold filed-emission gun and double hexapole Cs correctors (CEOS GmbH, Heidelberg, Germany). Dynamic secondary ion mass spectroscopy (SIMS) was carried out on a Cameca IMS-5FE7 system using $\mathrm{Cs}^{+}$primary ions with a beam current of $3 \mathrm{nA}$. Solid-state ${ }^{39} \mathrm{~K}$ NMR spectra were obtained on a JNM-ECZ600R widebore spectrometer.

DFT calculation. The crystal structures of $\mathrm{Na}_{0.500} \mathrm{~K}_{0.055} \mathrm{MnO}_{2}, \mathrm{Na}_{0.220} \mathrm{~K}_{0.055} \mathrm{MnO}_{2}$, and $\mathrm{Na}_{0.275} \mathrm{MnO}_{2}$ were simulated using Vienna ab-initio simulation package (VASP). The generalized gradient approximation (GGA) of exchange-correlation energy, Perdew-Burke-Eznerhof (PBE) functional, was used with its corresponding projector augmented-wave pseudopotentials ${ }^{31-34}$. A Hubbard $U$ term of 3.9 is adopted to better describe the strong correlation of $\mathrm{Mn} 3 d$ electrons. The slight difference between the simulated formulas and the obtained composition is due to that the number of $\mathrm{K}$ and $\mathrm{Na}$ atoms can only be integral in a unit cell, and such difference can be reasonably ignored. All optimization calculations adopted a $4 \times$ $4 \times 4$ Monkhorst-Pack ${ }^{51}$ k-point grid and a cutoff energy of $400 \mathrm{eV}$, and a higher cutoff of $450 \mathrm{eV}$ and a $6 \times 6 \times 4 \mathrm{k}$-point grid were applied for DOS and charge calculations for enhanced accuracy. First-principle molecular dynamics calculations, which adopt an NVT ensemble at $1000 \mathrm{~K}$, were carried out using a single I point to balance the accuracy and cost. Atomic positions and cell vectors were fully optimized until all force components were less than $0.02 \mathrm{eV} \AA^{-1}$. The trajectory of MD simulation was further analyzed using Rigorous Investigation of Networks Generated using Simulations (R.I.N.G.S.) code to obtain MSD statistics. The COHP calculations were carried out using Local-Orbital Basis Suite towards ElectronicStructure Reconstruction (LOBSTER) code. The diffusion energy barriers are calculated using climbing-image nudged elastic band (CI-NEB) method with a single $\Gamma$ point.

\section{Data availability}

The data that support the findings of this study are available from the corresponding author upon reasonable request.

Received: 16 June 2020; Accepted: 15 March 2021;

Published online: 15 April 2021

\section{References}

1. House, R. A. et al. Superstructure control of first-cycle voltage hysteresis in oxygen-redox cathodes. Nature 577, 502-508 (2020).

2. Zhang, K. et al. Manganese based layered oxides with modulated electronic and thermodynamic properties for sodium ion batteries. Nat. Commun. 10 5203 (2019).

3. Li, Q. et al. Both cationic and anionic co-(de)intercalation into a metal-oxide material. Joule 2, 1134-1145 (2018)

4. Lee, G.-H. et al. Reversible anionic redox activities in conventional $\mathrm{LiNi}_{1 / 3} \mathrm{Co}_{1 /}$ ${ }_{3} \mathrm{Mn}_{1 / 3} \mathrm{O}_{2}$ Cathodes. Angew. Chem. Int. Ed. 59, 8681-8688 (2020).

5. Liu, Y. et al. Mitigation of Jahn-Teller distortion and $\mathrm{Na}^{+} /$vacancy ordering in distorted manganese oxide cathode material by Li substitution. Chem. Sci. https://doi.org/10.1039/D0SC05427E (2020).

6. Ren, M., Fang, H., Wang, C., Li, H. \& Li, F. Advances on manganese-oxidebased cathodes for Na-ion batteries. Energy Fuels 34, 13412-13426 (2020).

7. Wang, C., Du, D., Song, M., Wang, Y. \& Li, F. A high-power $\mathrm{Na}_{3} \mathrm{~V}_{2}\left(\mathrm{PO}_{4}\right)_{3}-\mathrm{Bi}$ sodium-ion full battery in a wide temperature range. Adv. Energy Mater. 9, 1900022 (2019).

8. Wang, P. F. et al. An abnormal 3.7 volt O3-type sodium-ion battery cathode. Angew. Chem. Int. Ed. 57, 8178-8183 (2018).

9. Zhao, C. L. et al. Ti Substitution facilitating oxygen oxidation in $\mathrm{Na}_{2 / 3} \mathrm{Mg}_{1 /}$ ${ }_{3} \mathrm{Ti}_{1 / 6} \mathrm{Mn}_{1 / 2} \mathrm{O}_{2}$ cathode. Chem 5, 2913-2925 (2019).

10. You, Y. et al. Insights into the improved high-voltage performance of Liincorporated layered oxide cathodes for sodium-ion batteries. Chem $\mathbf{4}$, 2124-2139 (2018).
11. Lei, K. et al. Dual interphase layers in situ formed on a manganese-based oxide cathode enable stable potassium storage. Chem 5, 3220-3231 (2019).

12. Li, X. et al. Direct visualization of the Jahn-Teller effect coupled to Na ordering in $\mathrm{Na}_{5 / 8} \mathrm{MnO}_{2}$. Nat. Mater. 13, 586-592 (2014).

13. Vergnet, J., Saubanère, M., Doublet, M.-L. \& Tarascon, J.-M. The structural stability of P2-layered Na-based electrodes during anionic redox. Joule $\mathbf{4}$, 420-434 (2020).

14. Kobayashi, W. et al. Thermal expansion in layered $\mathrm{Na}_{\mathbf{x}} \mathrm{MO}_{2}$. Sci. Rep. 8, 3988 (2018).

15. Zhao, C. L. et al. Revealing high Na-content P2-type layered oxide as advanced sodium-ion cathodes. J. Am. Chem. Soc. 142, 5742-5750 (2020).

16. Xiang, X., Zhang, K. \& Chen, J. Recent advances and prospects of cathode materials for sodium-ion batteries. Adv. Mater. 27, 5343-5364 (2015).

17. Kumakura, S., Tahara, Y., Kubota, K., Chihara, K. \& Komaba, S. Sodium and manganese stoichiometry of P2-Type $\mathrm{Na}_{2 / 3} \mathrm{MnO}_{2}$. Angew. Chem. Int. Ed. 55, 12760-12763 (2016)

18. Kulka, A. et al. Influence of $\mathrm{Na} / \mathrm{Mn}$ arrangements and $\mathrm{P} 2 / \mathrm{P}^{2} 2$ phase ratio on the electrochemical performance of $\mathrm{Na}_{\mathrm{x}} \mathrm{MnO}_{2}$ cathodes for sodium-ion batteries. J. Mater. Chem. A 8, 6022-6033 (2020).

19. Clément, R. J. et al. Structurally stable Mg-doped $\mathrm{P} 2-\mathrm{Na}_{2 / 3} \mathrm{Mn}_{1-\mathrm{y}} \mathrm{Mg}_{\mathrm{y}} \mathrm{O}_{2}$ sodium-ion battery cathodes with high rate performance: insights from electrochemical, NMR and diffraction studies. Energy Environ. Sci. 9, 3240-3251 (2016)

20. Kumakura, S., Tahara, Y., Sato, S., Kubota, K. \& Komaba, S. P’2-Na ${ }_{3} \mathrm{Mn}_{0.9} \mathrm{Me}_{0.1} \mathrm{O}_{2}(\mathrm{Me}=\mathrm{Mg}$, Ti, $\mathrm{Co}, \mathrm{Ni}, \mathrm{Cu}$, and $\mathrm{Zn})$ : correlation between orthorhombic distortion and electrochemical property. Chem. Mater. 29 8958-8962 (2017)

21. Yabuuchi, N. et al. P2-type $\mathrm{Na}_{\mathrm{x}}\left[\mathrm{Fe}_{1 / 2} \mathrm{Mn}_{1 / 2}\right] \mathrm{O}_{2}$ made from earth-abundant elements for rechargeable Na batteries. Nat. Mater. 11, 512-517 (2012).

22. Yoshida, J. et al. New $\mathrm{P} 2-\mathrm{Na}_{0.70} \mathrm{Mn}_{0.60} \mathrm{Ni}_{030} \mathrm{Co}_{0.10} \mathrm{O}_{2}$ layered oxide as electrode material for Na-ion batteries. J. Electrochem. Soc. 161, A1987-A1991 (2014).

23. Paulsena, J. M. \& Dahn, J. R. Studies of the layered manganese bronzes, $\mathrm{Na}_{2}$ ${ }_{3}\left[\mathrm{Mn}_{1-\mathrm{x}} \mathrm{M}_{\mathrm{x}}\right] \mathrm{O}_{2}$ with $\mathrm{M}=\mathrm{Co}, \mathrm{Ni}, \mathrm{Li}$, and $\mathrm{Li}_{2 / 3}\left[\mathrm{Mn}_{1-\mathrm{x}} \mathrm{M}_{\mathrm{x}}\right] \mathrm{O}_{2}$ prepared by ionexchange. Solid State Ion. 126, 3-24 (1999).

24. Pang, $\mathrm{W}$. et al. $\mathrm{P} 2$-type $\mathrm{Na}_{2 / 3} \mathrm{Mn}_{1-\mathrm{x}} \mathrm{Al}_{\mathrm{x}} \mathrm{O}_{2}$ cathode material for sodium-ion batteries: Al-doped enhanced electrochemical properties and studies on the electrode kinetics. J. Power Sources 356, 80-88 (2017).

25. Wang, P.-F., You, Y., Yin, Y.-X. \& Guo, Y.-G. Layered oxide cathodes for sodium-ion batteries: phase transition, air stability, and performance. $A d v$. Energy Mater. 8, 1701912 (2018).

26. Song, J. et al. Role of oxygen vacancies on the performance of $\mathrm{Li}\left[\mathrm{Ni}_{0.5-\mathrm{x}} \mathrm{Mn}_{1.5}\right.$ ${ }_{+}^{+} \mathrm{J}_{4}(\mathrm{x}=0,0.05$, and 0.08$)$ spinel cathodes for lithium-ion batteries. Chem. Mater. 24, 3101-3109 (2012).

27. Clément, R. J. et al. Structurally stable Mg-doped $\mathrm{P} 2-\mathrm{Na}_{2 / 3} \mathrm{Mn}_{1-\mathrm{y}} \mathrm{Mg}_{\mathrm{y}} \mathrm{O}_{2}$ sodium-ion battery cathodes with high rate performance: insights from electrochemical, NMR and diffraction studies. Energy Environ. Sci. 9, 3240-3251 (2016)

28. Bianchini, M., Wang, J., Clément, R. \& Ceder, G. A first-principles and experimental investigation of nickel solubility into the $\mathrm{P} 2 \mathrm{Na}_{\mathrm{x}} \mathrm{CoO}_{2}$ sodiumion cathode. Adv. Energy Mater. 8, 1801446 (2018).

29. Scheler, U., Blümich, B. \& Spiess, H. W. Spinning sidebands from chemical shift anisotropy in ${ }^{13} \mathrm{C}$ MAS imaging. Solid State Nucl. Magn. Reson. 2, 105-110 (1993).

30. Kövér, L. et al. Chemical effects on F KLL Auger spectra in fluorides. J. Vac Sci. Technol. A 19, 1143-1149 (2001).

31. Perdew, J. P., Burke, K. \& Ernzerhof, M. Generalized gradient approximation made simple. Phys. Rev. Lett. 77, 3865-3868 (1996).

32. Kresse, G. \& Furthmüller, J. Efficient iterative schemes for ab initio totalenergy calculations using a plane-wave basis set. J. Phys. Rev. B 54, 11169-11186 (1996).

33. Blöchl, P. E. Projector augmented-wave method. Phys. Rev. B 50, 17953-17979 (1994).

34. Kresse, G. \& Joubert, D. From ultrasoft pseudopotentials to the projector augmented-wave method. Phys. Rev. B 59, 1758-1775 (1999).

35. Kang, K., Meng, Y. S., Bréger, J., Grey, C. P. \& Ceder, G. Electrodes with high power and high capacity for rechargeable lithium batteries. Science 311, 977-980 (2006).

36. Chen, $\mathrm{X}$. et al. Super charge separation and high voltage phase in $\mathrm{Na}_{\mathrm{x}} \mathrm{MnO}_{2}$ Adv. Funct. Mater. 28, 1805105 (2018).

37. Li, X. et al. Jahn-Teller assisted $\mathrm{Na}$ diffusion for high performance $\mathrm{Na}$ ion batteries. Chem. Mater. 28, 6575-6583 (2016).

38. Li, Y. M. et al. Air-stable copper-based $\mathrm{P} 2-\mathrm{Na}_{7 / 9} \mathrm{Cu}_{2 / 9} \mathrm{Fe}_{1 / 9} \mathrm{Mn}_{2 / 3} \mathrm{O}_{2}$ as a new positive electrode material for sodium-ion batteries. Adv. Sci. 2, 1500031 (2015).

39. Talaie, E., Duffort, V., Smith, H. L., Fultz, B. \& Nazar, L. F. Structure of the high voltage phase of layered $\mathrm{P} 2-\mathrm{Na}_{2 / 3-\mathrm{z}}\left[\mathrm{Mn}_{1 / 2} \mathrm{Fe}_{1 / 2}\right] \mathrm{O}_{2}$ and the positive effect of Ni substitution on its stability. Energy Environ. Sci. 8, 2512-2523 (2015).

40. Rong, X. H. et al. Anionic redox reaction-induced high-capacity and lowstrain cathode with suppressed phase transition. Joule 3, 503-517 (2019). 
41. Ma, C. et al. Exploring oxygen activity in the high energy P2-type $\mathrm{Na}_{0.78} \mathrm{Ni}_{0.23} \mathrm{Mn}_{0.69} \mathrm{O}_{2}$ cathode material for $\mathrm{Na}$-ion batteries. J. Am. Chem. Soc. 139, 4835-4845 (2017).

42. Luo, C., Langrock, A., Fan, X., Liang, Y. \& Wang, C. P2-type transition metal oxides for high performance Na-ion battery cathodes. J. Mater. Chem. A 5, 18214-18220 (2017).

43. Yabuuchi, Y. et al. New O2/P2-type Li-excess layered manganese oxides as promising multi-functional electrode materials for rechargeable $\mathrm{Li} / \mathrm{Na}$ batteries. Adv. Energy Mater. 4, 1301453 (2014).

44. Jian, Z. et al. Atomic structure and kinetics of NASICON $\mathrm{Na}_{\mathrm{x}} \mathrm{V}_{2}\left(\mathrm{PO}_{4}\right)_{3}$ cathode for sodium-ion batteries. Adv. Funct. Mater. 24, 4265-4272 (2014)

45. Kang, W. et al. Copper substituted P2-type $\mathrm{Na}_{0.67} \mathrm{Cu}_{\mathrm{x}} \mathrm{Mn}_{1-\mathrm{x}} \mathrm{O}_{2}$ : a stable highpower sodium-ion battery cathode. J. Mater. Chem. A 3, 22846-22852 (2015).

46. Rodríguez-Carvajal, J. Recent advances in magnetic structure determination by neutron powder diffraction. Phys. B Condens. Matter 192, 55-69 (1993)

47. Hammersley, A. P. Fit2D version 9.129 reference manual version 3.1, ESRF Inter. Rep. No. ESRF98HA01T (1998).

48. Juhás, P. et al. PDFgetX3: a rapid and highly automatable program for processing powder diffraction data into total scattering pair distribution functions. J. Appl. Crystallogr. 46, 560-566 (2013).

49. Ravel, B. \& Newville, M. ATHENA, ARTEMIS, HEPHAESTUS: data analysis for X-ray absorption spectroscopy using IFEFFIT. J. Synchrotron. Radiat. 12, 537-541 (2005).

50. Momma, K. \& Izumi, F. VESTA 3 for three-dimensional visualization of crystal, volumetric and morphology data. J. Appl. Crystallogr. 44, 1272-1276 (2011).

51. Monkhorst, H. J. \& Pack, J. D. Special points for brillonin-zone integrations. Phys. Rev. B 13, 5188-5192 (1976).

\section{Acknowledgements}

Financial supports from National Natural Science Foundation of China (grant No. 21835004, 21822506, and 51671107), Tianjin Natural Science Foundation (grant No. 19JCJQJC62400), and the 111 project of B12015 are acknowledged. Dedicated to the 100th anniversary of Chemistry at Nankai University.

\section{Author contributions}

F.L. conceived the concept and supervised the work; C.W. designed and performed the experiments; L.L. and J.C. performed the DFT calculations; L.L. and S.Z. analyzed the
DFT data; C.W. and Y.L. carried out in situ and ex situ XRD; H.Y. and Y.Y. carried out the PDF experiments; S.L., G.-H.L., and Y.-M.K. performed the XAFS analyses; R.L. measured and analyzed SIMS data; F.L. and C.W. wrote the manuscript; all the authors contributed to discussion and revision of the manuscript.

\section{Competing interests}

The authors declare no competing interests.

\section{Additional information}

Supplementary information The online version contains supplementary material available at https://doi.org/10.1038/s41467-021-22523-3.

Correspondence and requests for materials should be addressed to F.L.

Peer review information Nature Communications thanks the anonymous reviewers for their contribution to the peer review of this work.

Reprints and permission information is available at http://www.nature.com/reprints

Publisher's note Springer Nature remains neutral with regard to jurisdictional claims in published maps and institutional affiliations.

(c) (i) Open Access This article is licensed under a Creative Commons Attribution 4.0 International License, which permits use, sharing, adaptation, distribution and reproduction in any medium or format, as long as you give appropriate credit to the original author(s) and the source, provide a link to the Creative Commons license, and indicate if changes were made. The images or other third party material in this article are included in the article's Creative Commons license, unless indicated otherwise in a credit line to the material. If material is not included in the article's Creative Commons license and your intended use is not permitted by statutory regulation or exceeds the permitted use, you will need to obtain permission directly from the copyright holder. To view a copy of this license, visit http://creativecommons.org/ licenses/by/4.0/.

(C) The Author(s) 2021 